\title{
SELF-ASSESSMENT OF ENGLISH READING SKILLS IN GRADE 6
}

\author{
Evija Latkovska', Santa Aleksejeva ${ }^{2}$ \\ ${ }^{1}$ University of Latvia, Latvia \\ 2 Mezciems Primary School, Latvia
}

\begin{abstract}
One of topicalities in the field of education in the $21^{\text {st }}$ century is a necessity to share responsibility. Namely, students should learn to be more responsible for how and what they learn, whereas teachers should learn to share the ownership of the learning process with students, letting them be more involved in it as decision-makers. One way how teachers can encourage students become more conscious of the learning process is to engage them in self-assessment of their learning and learning outcomes. One of self-assessment tools in language education is the European Language Portfolio (the ELP). Apart from different ELPS for adults, there is a portfolio for students in Latvia: My Language Portfolio - The European Language Portfolio for young learners (age 7-12) in the paperback and digital versions.

In the present study, the researchers explore how self-assessment can be incorporated in the English language lessons by offering self-assessment activities and the ELP to Grade 6 students to work on their reading skills. Reading skills make the basis for every person's literacy as reading does not only concern reading itself, it is also about being able to master general knowledge of any other school subject and the world knowledge in general. Thus, the aim of the research is to find out how self-assessment can be used to improve reading skills in English in Grade 6.

A case study was carried out for one month in one primary school in Riga, the research sample being two separate groups of Grade 6 students, in total - 26. The researchers analysed and interpreted data collected from assessment and self-assessment of reading activities, questionnaires filled out by students. The main findings of the research show that self-assessment can successfully be incorporated in lessons of English of Grade 6 students as it increases students' motivation to learn and their reading skills improve. That could be based on the fact that self-assessment allows students to take more ownership of their learning process and learning outcomes, that way making students become more responsible. However, overall progress is not immense and for students who are more competent in English, improvement of their reading skills can barely be traced. It has to be highlighted that students, whose confidence in their English reading skills is lower, benefit from self-assessment more. It could be explained by students' conscious work on particular problems with reading in English they discover while completing self-assessment activities.
\end{abstract}

Keywords: English as a foreign language, English Language Portfolio, primary school students, self-assessment, reading skills. 


\section{Introduction}

Learning a new language includes a person's work on multiple skills. Among four basic language skills there is reading as the basis of a person's literacy. Literacy in the $21^{\text {st }}$ century and, more importantly, in the time of the COVID-19 pandemic has to be perceived as a skill to wisely deal with overload of information both in paper and online, to be able to distinguish between real facts and fake information (Organisation for Economic Co-operation and Development [OECD], 2021). Therefore it is of utmost importance that reading skills, including critical reading, are learnt at school, and not only in the native language lessons, but also in lessons of English as this is a global language. This is essential because reading as a skill serves two purposes. First of all, students learn to read, either in their native or a foreign language. Secondly, they use reading to learn (Littlejohn \& Hicks, 1996), thus becoming more self-directed in their learning process. Furthermore, reading may be perceived as a tool that ensures intercultural communication in different fields, for example, social, professional, academic, and personal (Byram \& Hu, 2003). However, learning to read in a foreign language is different from reading in a mother tongue. Teachers should pay attention to the fact that the amount of unknown words and language structures do not make students perceive reading as something boring and difficult (Farell, 2009; Harmer, 2007; Scrivener, 2005). To lessen the impact of possible challenges for students, teachers are advised to follow eight principles of reading instruction for the English language learners (Nation \& McAlister, 2020; Farell, 2009; Harmer, 2007; Scrivener, 2005; Day \& Bamford 2002):

1. Students are encouraged to reflect on what has been read;

2. Students are exposed to a variety of reading types (for example, reading aloud and silently, reading combined with listening to the text);

3. Students are taught different reading strategies (for example, skimming and scanning);

4. Students are taught to recognise various text types (for example, a fairy-tale, an interview, a fable, etc.);

5. Students are presented vocabulary building techniques;

6. Students are encouraged to engage in extensive reading activities (reading as a hobby);

7. Teachers learn to plan effective reading lessons;

8. Teachers invite students to participate in authentic reading assessment (besides technical comprehension check-up questions, there also has to be students' self-assessment of reading skills).

This supports the idea of a shift of learning paradigms in the $21^{\text {st }}$ century, students becoming more autonomous and being more active participants of 
their learning process by developing an ability to reflect on their work, including reading. Boud (2013) states that self-assessment means a person's ability to apply certain standards or criteria to one's work and to make judgements about the level one is at in meeting them. Everhard and Murphy (2015) present three stages of assessment and their link to the language and learning style development, emphasising that with each stage students take on more responsibility for their learning and become more self-reliant and autonomous. The three previously mentioned stages of assessment are as follows: 1) dependent stage with full dependence on external assessment, 2) co-operative stage with collaborative self- and external assessment, and 3) independent stage with full reliance on independent self-assessment. In the context of Latvia, the competence-based approach to the curriculum highlights a necessity for students to get to the second stage of assessment, which means mastering a skill of self-assessment of their learning and learning outcomes (Skola 2030, 2018). Selfassessment can help students develop a learning style in which they are more aware of their strengths and weaknesses, create more ownership of their learning, and stimulate motivation and involvement in the learning process (Afflerbach, 2014; Boud, 2013; Bullock, 2010; Gonzales, 2008).

Self-assessment in foreign language learning can be performed by the use of the European Language Portfolio, which aims at recording and reflecting one's language learning and intercultural experiences (Council of Europe [CoE], n. d.). The origins of the ELP date back to 2001, and since then most European countries have taken part in the initiative and besides portfolios for adults have created European Language Portfolios for learners at school in both in English and their native language, which allows students more flexible and individual way of working on their learning. Research on the use of ELP in the foreign language classroom, has also proven it to be a particularly useful tool to develop student learning autonomy (Gonzales, 2008). Murphy and Everhard (2015) point out that self-assessment creates a more balanced situation in the learning process as teachers and students then share mutual responsibility for students' learning process and learning outcomes.

As regards benefits of self-assessment on reading at school, Afflerbach (2014) argues that self-assessment develops the sense of a more self-driven learning process and increases students' reading confidence letting students perceive success in reading as something they can control. Self-assessment of learning, including reading, must be incorporated in the learning process as early as possible (Afflerbach, 2014; Boud, 2013; Boud 1991). Primary school students should be introduced to the use of checklists as they provide models of self-assessment thinking, and prompt students to ask self-assessment questions (Afflerbach, 2014). European Language Portfolio for students offers certain checklists in a form of 'can do' statements (CoE, n. d.). 
To sum up, reading skills are crucial in the $21^{\text {st }}$ century as people have to be able to deal with the overload of a variety of true and fake information. Self-assessment of one's reading skills can help a person take decisions about one's reading competence and set goals for further development. Consequently, the aim of the research is to find out how self-assessment can be used to improve reading skills in English in Grade 6 as it is suggested that self-assessment should be incorporated in the learning process as early as possible.

\section{Method}

In order to reach the aim of the particular small scale research in education, a case study was chosen as a research method (Hamilton, 2018; Cropley, 2002). It lasted for a month, in November of 2020 in one primary school in Latvia. Appropriate for research in education, a non-probability convenience research sample (Cohen \& Manion, 2007) was chosen - two different groups of Grade 6: 6a (14 students) and 6b (12 students). Reasons for choosing Grade 6 as a research sample were multiple. Firstly, Grade 6 students have already worked on reading skills but they have to continue their work to improve them. Secondly, self-assessment of the learning process and learning outcomes in Grade 6 is important in the situation of Latvia as Grade 6 students should be prepared for the work according to the new competence-based approach to education which the students will face in Grade 7, where self-assessment is an important aspect of the learning process (Skola 2030, 2018). Thirdly, considering the circumstances, it was chosen to work with Grade 6 as their learning process continued physically at school and was not interrupted by the pandemic at the time the case study was performed. The data collection methods were document analysis (the students' self-assessment and teacher's assessment of reading activities) and a questionnaire for the students. Triangulation of the data was performed (Hamilton, 2018; Cropley, 2002).

Both authors of the article were actively involved in the development of the research methodology and analysis of the results as their cooperation model was the one of a university lecturer and an in-service teacher participating in further education activities and at the time having a teaching practice envisaged by the study programme. The teaching and learning process itself was conducted by the second author of the article.

\section{The ELP}

The case study began with encouraging the students fill out the European Language Portfolio. The students had to complete the ELP created by the Latvian Association of Teachers of English (LATE) and the Latvian Language 
Agency: "My Language Portfolio, The European Language Portfolio for young learners (age 7-12)" (the Latvian version) (Latvian Association of Teachers of English [LATE] \& Latvian Language Agency, 2007). The Latvian language was chosen to have an easier self-assessment process for the students. The whole portfolio was not used instead it was a small section of it focusing on the reading skills (p.23). The students were asked to complete the ELP can-do statements on the first and the last day of the case study to compare if there were changes in how students self-evaluate their reading skills having a month of reading and self-assessment tasks in between.

Table 1. Section from the ELP to be completed by the students at the beginning and end of the case study.

\begin{tabular}{|c|c|c|c|c|}
\hline & & $\begin{array}{l}\text { I can do it } \\
\text { well }\end{array}$ & $\begin{array}{l}\text { I can } \\
\text { partially } \\
\text { do it }\end{array}$ & $\begin{array}{l}\text { I cannot do } \\
\text { it, yet }\end{array}$ \\
\hline 1. & $\begin{array}{l}\text { I can read and understand a } \\
\text { short and simple text about } \\
\text { familiar topics. }\end{array}$ & & & \\
\hline 2. & $\begin{array}{l}\text { I can read and understand } \\
\text { simple messages and e-mail } \\
\text { letters. }\end{array}$ & & & \\
\hline 3. & $\begin{array}{l}\text { I can read and understand } \\
\text { simple private letters. }\end{array}$ & & & \\
\hline 4. & $\begin{array}{l}\text { I can find necessary information } \\
\text { in simple texts. }\end{array}$ & & & \\
\hline 5. & $\begin{array}{l}\text { I understand words and phrases } \\
\text { in simple daily directions and } \\
\text { announcements. }\end{array}$ & & & \\
\hline 6. & $\begin{array}{l}\text { I understand certain information } \\
\text { in simple everyday materials - } \\
\text { advertisements, lists, menu, } \\
\text { programmes, etc. }\end{array}$ & & & \\
\hline 7. & $\begin{array}{l}\text { I can also distinguish what type } \\
\text { of text I am reading (interview, } \\
\text { article, description, etc.). }\end{array}$ & & & \\
\hline
\end{tabular}

\section{Reading activities, students' self-assessment and assessment by the teacher of the students' reading skills}

During the case study the students worked on three main reading skills: 1) identifying the main idea of the text (skimming); 2) identifying the type of text; 3) finding information in text to answer questions (scanning). It was chosen to work on these three skills as they are included in the model programme of English as a first foreign language (Skola 2030, 2018, 
pp. 58-65). All in all there were 12 reading assignments based on the reading skills mentioned in the ELP table (see Table 1) and they were on the topic Animals as it happened to be the topic that had to be covered at the time of the case study. Reading activities were presented using reading materials from the education sites excellentesl4u.com; lingoda.com; twinkle. com; uzdevumi.lv.

As the research also focused on self-assessment, after each reading task each student had to fill out an electronic self-assessment task created in Google forms. The self-assessment task was identical after each reading activity. All in all, there were 12 students' self-assessment tasks.

Table 2. Self-assessment task the students had to do after each reading activity

\begin{tabular}{|l|l|l|l|l|}
\hline & & $\begin{array}{l}\text { I can do it } \\
\text { well }\end{array}$ & $\begin{array}{l}\text { I can } \\
\text { partially } \\
\text { do it }\end{array}$ & $\begin{array}{l}\text { I cannot do } \\
\text { it, yet }\end{array}$ \\
\hline 1. & $\begin{array}{l}\text { I understand the main idea of } \\
\text { the text and I can talk about it } \\
\text { (skimming) }\end{array}$ & $\begin{array}{l}\text { text I am reading (for example: } \\
\text { article, interview, } \\
\text { film review) }\end{array}$ & & \\
\hline 3. & $\begin{array}{l}\text { I can find specific information in } \\
\text { the text } \\
\text { to answer questions (scanning) }\end{array}$ & & & \\
\hline
\end{tabular}

After every third reading activity, the teacher collected the students' responses on the reading activities as part of four teacher assessment sessions. In total, four students' reading activities were assessed by the teacher.

\section{Questionnaire for the students at the end of the research}

At the end of the research students were given a questionnaire to reflect on the month-long reading process which was complemented by self-assessment. Students reflected on how they felt about their reading skills at the end of the case study and if self-assessment had helped them in the learning process. The Likert scale (from 1 to 5 ) was used to express the opinion on the following questions: 1) How much do you think your reading skills have improved over the past month? 2) How much do you think self-assessment helped to improve your reading skills? 3) Do you feel like a more confident reader in English? 


\section{Results}

The results of the research were analysed separately in Grade 6a and in Grade 6b. As the average scores in tests had been higher in Grade 6a than in Grade $6 \mathrm{~b}$, it was of interest to see if there was a difference in the development of students' reading skills as they were encouraged to participate in self-assessment activities.

\section{The Results of the ELP used in lessons of English}

Seven ELP statements completed by the students at the beginning and the end of the case study are analysed using the percentage (Table 3 and Table 4).

When evaluating reading comprehension (Statement 1), students in both grades did not see a difference in improving their ability to read and understand a short, simple text about familiar topics at the beginning and the end of the study.

However, as regards their skill to understand simple messages, students showed an increase in their abilities (Statement 2). Both grades saw their results as improved. In Grade 6a, initially $67 \%$ of students admitted that they could read simple messages and e-mails, but by the end of the case study, all the students marked that they could read and understand simple messages and e-mails. In group $6 \mathrm{~b}$ the proportion that could do this skill partially decreased (from $22 \%$ to $7 \%$ ) and in $93 \%$ of the students at the end admitted they could do that well.

In Statement 3 - reading and understanding a simple personal letter, some changes were seen in Grade 6a, but substantial changes there were for Grade $6 \mathrm{~b}$ (from $38 \%$ to $81 \%$ ) - students noting they could do that well at the end of the study.

The data in Statement 4 showed that finding specific information in a text as a skill had improved. Even though Grade 6a had better results at the beginning of the case study, both grades showed a similar trend with more students claiming to be able to perform the skill well.

Asked about their ability to understand words and phrases in simple everyday signs (Statement 5), the students in both grades provided different answers. While in Grade 6a at the end of the case study all the students admitted they could do that well, the students of Grade 6b saw a decrease in confidence (from $82 \%$ to $78 \%$ ).

In Statement 6 there were no substantial changes in both grades. The same was true for Statement 7 in Grade 6a, but a noticeable change in Grade $6 \mathrm{~b}$ (from $75 \%$ to $91 \%$ ) - more students admitted that at the end of the case study they were able to distinguish different types of texts. 
Table 3. Grade 6a students' opinions on their reading skills at the beginning and the end of the case study

\begin{tabular}{|c|c|c|c|c|c|c|c|}
\hline & \multirow[t]{2}{*}{ 6a (14 students) } & \multicolumn{2}{|c|}{ YES \% } & \multicolumn{2}{|c|}{ PARTLY \% } & \multicolumn{2}{|c|}{ NOT YET \% } \\
\hline & & Start & End & Start & End & Start & End \\
\hline 1. & $\begin{array}{l}\text { I can read and understand a short and } \\
\text { simple text about familiar topics. }\end{array}$ & 100 & 100 & & & & \\
\hline 2. & $\begin{array}{l}\text { I can read and understand simple } \\
\text { messages and e-mail letters. }\end{array}$ & 67 & 100 & 33 & & & \\
\hline 3. & $\begin{array}{l}\text { I can read and understand simple } \\
\text { private letters. }\end{array}$ & 93 & 100 & 7 & & & \\
\hline 4. & $\begin{array}{l}\text { I can find necessary information in } \\
\text { simple texts. }\end{array}$ & 61 & 93 & 39 & 7 & & \\
\hline 5. & $\begin{array}{l}\text { I understand words and phrases } \\
\text { in simple daily directions and } \\
\text { announcements. }\end{array}$ & 79 & 100 & 21 & & & \\
\hline 6. & $\begin{array}{l}\text { I understand certain information } \\
\text { in simple everyday materials - } \\
\text { advertisements, lists, menu, } \\
\text { programmes, etc. }\end{array}$ & 82 & 82 & 18 & 18 & & \\
\hline 7. & $\begin{array}{l}\text { I can also distinguish what type of } \\
\text { text I am reading (interview, article, } \\
\text { description, etc.). }\end{array}$ & 100 & 100 & & & & \\
\hline
\end{tabular}

Table 4. Grade $6 \mathrm{~b}$ students' opinions on their reading skills at the beginning and the end of the case study

\begin{tabular}{|c|c|c|c|c|c|c|c|}
\hline & \multirow[t]{2}{*}{ 6b (12 students) } & \multicolumn{2}{|c|}{ YES \% } & \multicolumn{2}{|c|}{ PARTLY \% } & \multicolumn{2}{|c|}{ NOT YET \% } \\
\hline & & Start & End & Start & End & Start & End \\
\hline 1. & $\begin{array}{l}\text { I can read and understand a short and } \\
\text { simple text about familiar topics. }\end{array}$ & 82 & 82 & 12 & 12 & & \\
\hline 2. & $\begin{array}{l}\text { I can read and understand simple } \\
\text { messages and e-mail letters. }\end{array}$ & 78 & 93 & 22 & 7 & & \\
\hline 3. & $\begin{array}{l}\text { I can read and understand simple } \\
\text { private letters. }\end{array}$ & 38 & 81 & 50 & 19 & 12 & \\
\hline 4. & $\begin{array}{l}\text { I can find necessary information in } \\
\text { simple texts. }\end{array}$ & 67 & 90 & 23 & 10 & 10 & \\
\hline 5. & $\begin{array}{l}\text { I understand words and phrases } \\
\text { in simple daily directions and } \\
\text { announcements. }\end{array}$ & 82 & 78 & 18 & 22 & & \\
\hline 6. & $\begin{array}{l}\text { I understand certain information } \\
\text { in simple everyday materials - } \\
\text { advertisements, lists, menu, } \\
\text { programmes, etc. }\end{array}$ & 82 & 91 & 9 & 9 & 9 & \\
\hline 7. & $\begin{array}{l}\text { I can also distinguish what type of } \\
\text { text I am reading (interview, article, } \\
\text { description, etc.). }\end{array}$ & 75 & 91 & 16 & 9 & 9 & \\
\hline
\end{tabular}




\section{Results of the student self-assessment of reading skills}

To analyse the students' self-assessment of their reading skills performed in the reading activities during the case study after having used a self-assessment task after each of them, analysis of separate students is used, mentioning the highest and lowest numbers of students having chosen the certain answers. It has to be noted that not all 12 self-assessment tasks were completed by all the students of both grades.

As regards Grade 6a, the tendency is positive all the time as the majority of students considered themselves to be able of performing all three reading skills. More complicated than other skills in this Grade turned out to be scanning. Whereas in Grade $6 \mathrm{~b}$ not all the students were sure of their ability to perform all the reading skills, and for them the most complicated skill seemed to be skimming.

Table 5. Grade 6a students' opinion on their reading skills during the case study

\begin{tabular}{|l|c|l|l|}
\hline 6a (14 students) & $\begin{array}{l}\text { YES } \\
\text { students }\end{array}$ & $\begin{array}{l}\text { PARTIALLY } \\
\text { students }\end{array}$ & $\begin{array}{l}\text { NOT YET } \\
\text { students }\end{array}$ \\
\hline $\begin{array}{l}\text { I understand the main idea of the text } \\
\text { and I can talk about it.(skimming) }\end{array}$ & $7-12$ & $1-4$ & \\
\hline $\begin{array}{l}\text { I can distinguish the type of text I } \\
\text { am reading (for example: article, } \\
\text { interview, film review). }\end{array}$ & $7-12$ & $1-5$ & \\
\hline $\begin{array}{l}\text { I can find specific information in the } \\
\text { text to answer questions. (scanning) }\end{array}$ & $6-10$ & $4-7$ & \\
\hline
\end{tabular}

Table 6. Grade 6b students' opinion on their reading skills during the case study

\begin{tabular}{|l|c|c|c|}
\hline 6b (12 students) & $\begin{array}{l}\text { YES } \\
\text { students }\end{array}$ & $\begin{array}{l}\text { PARTIALLY } \\
\text { students }\end{array}$ & $\begin{array}{l}\text { NOT YET } \\
\text { students }\end{array}$ \\
\hline $\begin{array}{l}\text { I understand the main idea of the text } \\
\text { and I can talk about it.(skimming) }\end{array}$ & $5-9$ & $3-6$ & 1 \\
\hline $\begin{array}{l}\text { I can distinguish the type of text I } \\
\text { am reading (for example: article, } \\
\text { interview, film review). }\end{array}$ & $9-10$ & 2 & 1 \\
\hline $\begin{array}{l}\text { I can find specific information in the } \\
\text { text to answer questions. (scanning) }\end{array}$ & $7-9$ & $1-4$ & 1 \\
\hline
\end{tabular}

\section{Results of the teacher assessment of the students' reading skills}

The teacher's assessment of the students' reading skills based on the reading activities she had collected for four times during the case study, is shown using the percentage of students whose answers in the reading 
activities were correct. In spite of the fact, that for one month it was intensive work on reading skills using self-assessment, the teacher's assessment results differ from the positive tendencies the students' self-assessment had shown. For example, the data showed that in both grades the students' text scanning skill had decreased. An issue might be the level of difficulty of the collected assignments.

Table 7. The teacher's assessment of the students' answers for the reading activities

\begin{tabular}{|l|c|c|}
\hline \multirow{2}{*}{ 6a } & \multicolumn{2}{|c|}{$\begin{array}{l}\text { \% of the students having } \\
\text { correct answers in the } \\
\text { reading assignments }\end{array}$} \\
\cline { 2 - 3 } & Start & End \\
\hline scanning & 87 & 69 \\
\hline text type & 61 & 76 \\
\hline skimming & 76 & 76 \\
\hline
\end{tabular}

Table 8. The teacher's assessment of the students' answers for the reading activities

\begin{tabular}{|l|c|c|}
\hline \multirow{2}{*}{ bb } & \multicolumn{2}{|c|}{$\begin{array}{l}\text { \% of the students having } \\
\text { correct answers in the } \\
\text { reading assignments }\end{array}$} \\
\cline { 2 - 3 } & Start & End \\
\hline scanning & 80 & 51 \\
\hline text type & 31 & 79 \\
\hline skimming & 61 & 61 \\
\hline
\end{tabular}

\section{Results of the questionnaire for the students at the end of the research}

As regards the first question, the students in both grades considered that their reading skills had improved just the difference was that the students of Grade $6 \mathrm{~b}$ had felt it more which might be because of their lower general English knowledge scores at the beginning of the case study. Even though self-assessment as a useful tool was acknowledged in both grades, in Grade $6 \mathrm{~b}$ there were two students who had not seen it as too useful. That could be because of the students' low scores both at the beginning and the end of the case study. The third question about the reader's confidence - the majority of students of both grades admitted to having increased their confidence. However, in both grades there also were students who had not witnessed increase in their confidence as readers. 
Table 9. Students' opinion on the help of self-assessment of the development of their reading skills

\begin{tabular}{|l|c|c|c|c|c|}
\hline \multirow{2}{*}{ 6a } & \multicolumn{6}{|l|}{$\begin{array}{l}\text { Likert scale (1 - not at all; 5 - yes, very much); } \\
\text { the number of students }\end{array}$} \\
\cline { 2 - 7 } & $\mathbf{1}$ & $\mathbf{2}$ & $\mathbf{3}$ & $\mathbf{4}$ & $\mathbf{5}$ \\
\hline reading skills & 0 & 4 & 2 & 5 & 2 \\
\hline help of self-assessment & 0 & 0 & 4 & 7 & 2 \\
\hline reader's confidence & 0 & 1 & 2 & 8 & 2 \\
\hline
\end{tabular}

Table 10. Students' opinion on the help of self-assessment of the development of their reading skills

\begin{tabular}{|l|c|c|c|c|c|}
\hline \multirow{2}{*}{$\mathbf{6 b}$} & \multicolumn{6}{|l|}{$\begin{array}{l}\text { Likert scale (1 - not at all; 5 - yes, very much); } \\
\text { the number of students }\end{array}$} \\
\cline { 2 - 7 } & $\mathbf{1}$ & $\mathbf{2}$ & $\mathbf{3}$ & $\mathbf{4}$ & $\mathbf{5}$ \\
\hline reading skills & 0 & 1 & 0 & 6 & 5 \\
\hline help of self-assessment & 0 & 2 & 1 & 6 & 3 \\
\hline reader's confidence & 0 & 0 & 2 & 4 & 6 \\
\hline
\end{tabular}

\section{Discussion}

Even though on the whole the results of the study allow the researchers conclude that self-assessment tasks, including completion of the ELP, can be incorporated in the lessons of English in Grade 6 to improve students' reading skills, the certain details should be discussed.

First of all, the data shows that the students, who started the case study with lower scores in English, had the most noticeable progress after a month of additional reading activities and self-assessment tasks (Grade 6b). These students were engaged and motivated during the case study. Despite the fact that they had to spend more time to complete reading activities, they did not give up. That showed their motivation to work on their reading skills trying hard to self-assess their performance appropriately. It means that higher-achieving students need to be provided more complex reading activities and more detailed reading self-assessment criteria to be able to notice their progress (Grade 6a). One more aspect here might be the idea that low-achieving students tended to overrate their performance in general. However, self-assessment tasks helped them to become aware of the reality and pay attention to specific reading issues in next activities. The ELP statements can help the teacher and the students to spot reading skills which are important for students and areas that should be improved. 
Secondly, the topic Animals the reading material was on, might be a matter of taking a personal liking or disliking to it, thus leaving impact on the devotion of energy to the reading activities and self-assessment tasks. Moreover, it could also be the complexity of the reading activities they might seem easy or difficult for the certain students.

Thirdly, it has to be noted that over the course of the month, the students' motivation to participate in the learning process did not decreasethe majority of them were ready to read, to do the reading activities and complete the self-assessment tasks, which might mean that reading activities accompanied by self-assessment tasks impacted students' of Grade 6 thinking about reading and self-assessment in a positive way.

The fourth issue is the role of the teacher's assessment of the students' performance of reading activities. Namely, in the given period of time, which was one month, it might not be valid for a teacher to assess the students' progress of reading skills as the students' learning achievements were changing, that way making the teacher's assessment give a false impression of the state of art.

\section{Conclusions}

Self-assessment, including the ELP can-do statements, can be incorporated in the lessons of English in Grade 6 to improve students' reading skills if teachers apply relevant reading material and reading activities in lessons and design self-assessment tasks accordingly. More knowledgeable students should work not only with more challenging reading material, but their self-assessment tasks should be more challenging as well so that they can spot the progress and be interested to continue the development of their reading skills. If students feel too self-confident, self-assessment is a good tool to help these learners become aware of the reality, at the same time keeping their motivation not to give up. The most debatable issue is a teacher's assessment and its comparison with students' self-assessment of their reading skills if the teacher wants students to improve both in reading and self-assessing. Therefore, teachers should be careful with how they present their assessment scores to students so that students do not feel intimidated seeing that their self-assessment is higher in comparison with the teacher's assessment. All in all, students' perception of their self-assessment objectivity of their reading skills is of importance to maintain their motivation to participate both in reading activities and self-assessment tasks.

It has to be noted that the aforementioned conclusions are made based on the results of a small scale research in which the limited number of participants and duration of the study may be considered as its shortcomings. 
Nevertheless, the use of carefully selected and methodologically grounded research procedure makes it appropriate for being implemented in other pedagogical environments should the improvement of students' reading skills with the help of self-assessment be studied.

\section{References}

Afflerbach, P. (2009). Achieving Balance in Reading Assessment. Pearson. https://assets. pearsonschool.com/asset_mgr/current/201143/ReaMon094425Afflerbach_Final.pdf

Boud, D. (2013). Enhancing learning through self-assessment. London: Routledge.

Boud, D. (1991). HERDSA Green Guide No 5. Implementing student self-assessment (Second ed.). Campbelltown: The Higher Eucation Research and Development Socity of Australasia (HERDSA).

Bullock, D. (2010). Learner self-assessment: An investigation into teachers' beliefs. ELT Journal, 65(2), 114-125. https://doi.org/10.1093/elt/ccq041

Byram, M., \& Hu, A. (2017). Routledge encyclopedia of language teaching and learning. London: Routledge.

Cohen, L., Manion, L., \& Morrison, K. (2007). Research Methods in Education. Routledge Taylor \& Francis Group.

Council of Europe. (n.d.) European Language Portfolio. Strasbourg. https://www.coe.int/ en/web/portfolio/introduction

Cropley, A. (2002). Qualitative research methods. Zinātne.

Day, R. R., \& Bamford, J. (2002). Extensive reading in the second language classroom. Cambridge: Cambridge University Press.

Everhard, C. J., \& Murphy, L. (2015). Assessment and autonomy in language learning. Houndmills: Palgrave Macmillan.

Farrell, T. S. (2009). Teaching reading to English language learners: A reflective guide. Thousand Oaks, CA: Corwin Press.

Gonzalez, J. A. (2008). Promoting student autonomy through the use of the European Language Portfolio. ELT Journal, 63(4), 373-382. https://doi.org/10.1093/elt/ccn059

Hamilton, L. (2018). An Annotated Account of Case Study in Education Research. USA: OUP. https://www.oxfordbibliographies.com/view/document/obo-9780199756810/ obo-9780199756810-0201.xml

Harmer, J. (2007). The practice of English language teaching. Harlow, England: Pearson Longman.

Latvian Association of Teachers of English, \& Latvian Language Agency (2007). My Language Portfolio, The European Language Portfolio for young learners (age 7-12). Eiropas Padome. Portfelis_latvieshu_skoleniem.pdf (late.lv)

Littlejohn, A., \& Hicks, D. (2002). Cambridge English for schools. Cambridge: Cambridge Univ. Press.

Nation, I. S. P., \& Macalister, J. (2020). Teaching ESL/EFL Reading and Writing. Routledge. 
Organisation for Economic Co-operation and Development. (2021). 21 $1^{\text {st }}$ Century Readers: Developing Literacy Skills in a Digital World, PISA, OECD Publishing, Paris. https://doi. org/10.1787/a83d84cb-en.

Scrivener, J. (2005), Learning teaching. Oxford, U.K.: Macmillan.

Skola 2030. (2018). Model basic education programme of English as a first foreign language. https://mape.skola2030.lv/resources/5447 